\title{
An Exploratory Study of the Community Impacts of Service-Learning
}

\author{
Ka Hing Lau ${ }^{1}$, Maureen Yin Lee Chan², Cynthia Lok Sum Yeung ${ }^{3}$, and Robin Stanley \\ Snell ${ }^{4}$ \\ ${ }^{1,3}$ Office of Service Learning, Lingnan University, ${ }^{2}$ Department of Curriculum and Instruction, The Education \\ University of Hong Kong, and ${ }^{4}$ Department of Management, The Hang Seng University of Hong Kong
}

Cite as: Lau, K.H., Chan, M.Y.L., Yeung, C.L.S., Snell, R.S. (2021). An Exploratory Study of the Community Impacts of Service-Learning. Metropolitan Universities, 32(2), 106-128. DOI: 10.18060/25482

This is an open access article distributed under the terms of the Creative Commons Attribution License.

Editor: Valerie L. Holton, Ph.D.

\begin{abstract}
Research on community impacts from service-learning has been scarce, yet this area is worth exploring in order to understand how and why service-learning can make a difference. The current research sought to validate a conceptual framework (Lau \& Snell, 2020), which categorizes the impacts of service-learning on community partner organizations (CPOs) and on end-beneficiaries. Under the framework, impacts on end-beneficiaries can arise directly from service-learning interventions, but can also arise indirectly as a result of impacts on CPOs. For the research, semi-structured, one-to-one or focus group interviews were conducted with 13 CPO representatives, seeking their perceptions of positive and negative impacts of servicelearning. Most described impacts were positive, including, for CPOs: achieving project goals to further the CPO's mission; augmenting resources of the CPO; and gaining knowledge, insights, ideas and techniques. These positive impacts for CPOs appear to reflect three factors: alignment between service-learning project goals and the CPO's mission; mutual recognition of students' potential for transferring knowledge from universities to CPOs; and mutual understanding of students' status as semi-outsiders, free to challenge existing practices or systems. Further studies can explore impacts from the end-beneficiary's perspective, and adopt longitudinal and action research approaches.
\end{abstract}

Keywords: service-learning, community impacts, alignment, needs, knowledge transfer 


\section{Introduction}

Service-learning, as "a form of experiential education in which students engage in activities that address human and community needs together with structured opportunities intentionally designed to promote student learning and development" (Jacoby, 1996, p. 5), has been widely adopted in higher education across the globe (Ma, 2018; Shumer, Stanton \& Giles, 2017). Many higher education institutions adopting service-learning are urban and metropolitan universities (such as those in Hong Kong), following the tradition of emphasizing the use of knowledge for the betterment of society and educating students into becoming civic leaders with a sense of social responsibility (Bringle \& Hatcher, 1996; Kellogg, 1999). A large body of research has accumulated regarding the beneficial impacts of service-learning on student learning outcomes (e.g. Astin, Vogelgesang, Ikeda, \& Yee, 2000; Elyer, Giles, Stenson, \& Gray, 2001; Felten \& Clayton, 2011; Ngai, 2006, 2009; Shek \& Chan, 2013; Snell, Chan, Ma, \& Chan, 2015a), and a number of measurement instruments for capturing these impacts have been developed (e.g. Bringle, Philips, \& Hudson, 2004; Toncar, Reid, Burns, Anderson, \& Nguyen, 2006; Snell \& Lau, 2020).

However, the impact of service-learning on the community, an equally important stakeholder of this pedagogy, has received much less attention. More than 20 years ago, Giles \& Eyler (1998) identified the community impact of service-learning as one of the "top ten unanswered questions in service-learning research" and until recently the relative neglect of this question was still being criticized (e.g., Farahmandpour \& Shodjaee-Zrudlo, 2015).

One reason why community impact is important for service-learning is that meeting needs identified by the community predicts students' personal development through service-learning (Eyler \& Giles, 1999). Another, more fundamental reason is that mutually beneficial partnerships between campus and community form the basis of effective and sustainable service-learning (Holland \& Gelmon, 1998).

The dearth of research on the community impacts of service-learning may, in part, reflect the methodological challenges of defining the boundaries of the affected community, and of operationalizing measures of community impact (Cruz \& Giles, 2000). Moreover, the responses of some potential end-beneficiaries of service-learning, whom this article refers to as those individuals or groups, besides the CPO itself or employees of the CPO, who are perceived to benefit directly or indirectly from the service-learning intervention, may not be readily accessible. Most studies of community impact that have taken place have therefore been based on interviews with community partner organization (CPO) representatives as proxies of endbeneficiaries.

Another difficulty encountered in researching has been the lack of conceptual framework. There are few models in prior literature, and almost all of them consider community impact exclusively 
from the community partner's perspective (e.g., Clarke, 2003; Driscoll, Holland, Gelmon, \& Kerrigan, 1996; Gelmon, 2003). Lau and Snell (2020) recently developed a tripartite model comprising three components: the service-learning intervention, the $\mathrm{CPO}$, and the endbeneficiaries (see Figure 1).

Figure 1. A Conceptual Model for Assessing Community Impact

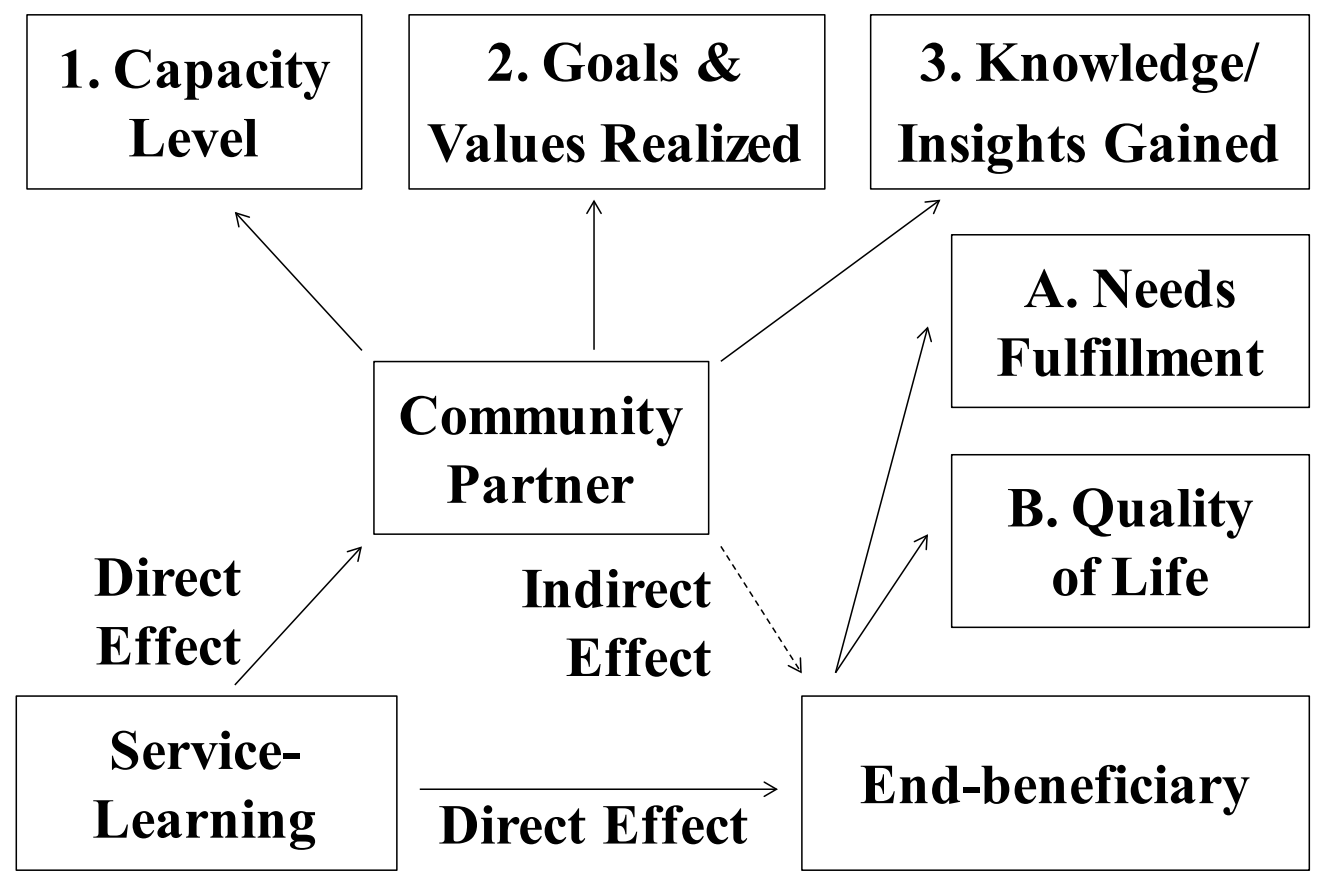

The model in Figure 1 identifies three domains of impact on the CPO: (1) increased capacity, (2) furtherance of goals and values, and (3) knowledge/ insights gained. The model also identifies (a) needs fulfillment and (b) quality of life as two broad impact domains for end-beneficiaries. A separate model, derived from Max-Neef (1991) classifies 36 types of end-beneficiary needs that could be positively impacted, comprising nine types (subsistence, protection, affection, understanding, participation, leisure, creation, identity and freedom) with four satisfiers for each (being, having, doing and interacting). Table 1 shows the 36 types of needs. 
Table 1. The Matrix of Needs and Satisfiers

\begin{tabular}{|c|c|c|c|c|}
\hline & Being & Having & Doing & Interacting \\
\hline Subsistence & 1. Health & $\begin{array}{l}\text { 2. Food, shelter, } \\
\text { work }\end{array}$ & $\begin{array}{l}\text { 3. Feed, procreate, } \\
\text { rest, work }\end{array}$ & $\begin{array}{l}\text { 4. Living and } \\
\text { social setting }\end{array}$ \\
\hline Protection & $\begin{array}{l}\text { 5. Care, } \\
\text { autonomy }\end{array}$ & $\begin{array}{l}\text { 6. Social security, } \\
\text { health systems, } \\
\text { rights, work }\end{array}$ & $\begin{array}{l}\text { 7. Co-operate, take } \\
\text { care of }\end{array}$ & $\begin{array}{l}\text { 8. Living and } \\
\text { social space }\end{array}$ \\
\hline Affection & $\begin{array}{l}\text { 9. Self-esteem, } \\
\text { respect, passion }\end{array}$ & $\begin{array}{l}\text { 10. Partnerships, } \\
\text { family }\end{array}$ & $\begin{array}{l}\text { 11. Take care of, } \\
\text { express emotions, } \\
\text { share, cultivate }\end{array}$ & $\begin{array}{l}\text { 12. Privacy, } \\
\text { intimacy, space of } \\
\text { togetherness }\end{array}$ \\
\hline Understanding & $\begin{array}{l}\text { 13. Curiosity, } \\
\text { rationality }\end{array}$ & $\begin{array}{l}\text { 14. Education, } \\
\text { communication }\end{array}$ & $\begin{array}{l}\text { 15. Investigate, } \\
\text { educate, analyze }\end{array}$ & $\begin{array}{l}\text { 16. Interaction } \\
\text { setting, schools }\end{array}$ \\
\hline Participation & $\begin{array}{l}17 . \\
\text { Adaptability, } \\
\text { willingness, }\end{array}$ & 18. Duties, rights & $\begin{array}{l}\text { 19. Co-operate, } \\
\text { interact }\end{array}$ & $\begin{array}{l}\text { 20. Participation } \\
\text { setting }\end{array}$ \\
\hline Leisure & $\begin{array}{l}\text { 21. Imagination, } \\
\text { humor, } \\
\text { sensuality, } \\
\text { tranquility }\end{array}$ & $\begin{array}{l}\text { 22. Games, peace of } \\
\text { mind }\end{array}$ & $\begin{array}{l}\text { 23. Memories, } \\
\text { fantasies, fun }\end{array}$ & $\begin{array}{l}\text { 24. Privacy, free } \\
\text { time, space of } \\
\text { closeness }\end{array}$ \\
\hline Creation & $\begin{array}{l}\text { 25. Passion, } \\
\text { imagination, } \\
\text { inventiveness }\end{array}$ & $\begin{array}{l}\text { 26. Abilities, skills, } \\
\text { methods }\end{array}$ & $\begin{array}{l}\text { 27. Invent, build, } \\
\text { design }\end{array}$ & $\begin{array}{l}\text { 28. Productive and } \\
\text { feedback settings }\end{array}$ \\
\hline Identity & $\begin{array}{l}\text { 29. Sense of } \\
\text { belonging, } \\
\text { consistency, } \\
\text { differentiation }\end{array}$ & $\begin{array}{l}\text { 30. Language, } \\
\text { religions, habits, } \\
\text { reference groups, } \\
\text { values }\end{array}$ & $\begin{array}{l}\text { 31. Integrate, know } \\
\text { oneself, grow }\end{array}$ & $\begin{array}{l}\text { 32. Settings which } \\
\text { one belongs to }\end{array}$ \\
\hline Freedom & $\begin{array}{l}\text { 33. Autonomy, } \\
\text { open- } \\
\text { mindedness }\end{array}$ & 34. Equal rights & $\begin{array}{l}\text { 35. Dissent, choose, } \\
\text { disobey }\end{array}$ & 36. Plasticity \\
\hline
\end{tabular}

Source: Max-Neef (1991)

Both Figure 1 and Table 1 draw attention to the importance of contributing to the fulfillment of end-beneficiaries' needs. In addition, Figure 1 indicates that impacts on end-beneficiaries may arise indirectly as a result of impacts on the $\mathrm{CPO}$, as well as arising directly from the servicelearning intervention. 
On the basis of interviews with representatives from CPOs that had been partners of servicelearning projects, the current study had two main goals. The first was to establish whether the model in Figure 1 and the taxonomy in Table 1 were supported by the accounts provided by the interviewees. The second was to identify any implied modifications to the model and the taxonomy arising from the interviewees' accounts, before any subsequent quantitative validation.

\section{Methods}

Interviewees

The authors adopted a qualitative approach by interviewing representatives of 13 CPOs that had collaborated in service-learning projects with one of four local universities. The latter comprised Lingnan University (LU), The Hong Kong Polytechnic University (HKPU), Hong Kong Baptist University (HKBU), and the Education University of Hong Kong (EdUHK). The four universities were invited to nominate CPOs that they worked with for several years on multiple projects. A quota sampling method was employed in selecting the CPOs based on two criteria: the type of service-learning project (i.e., direct, indirect, advocacy, or research), and the type of CPO (e.g., NGO, social enterprise). Invitations were sent to 16 local, Hong-Kong based CPOs, and representatives of 11 of them were interviewed (in one case two representatives were interviewed). Two overseas CPOs were also invited, in order to extend the generalizability of this study to overseas programs (see Table 2).

As shown in Table 3, all interviews referred to the perceived impacts of projects that involved direct and/or indirect service, while some also referred to projects that involved research and/or advocacy. Most CPOs represented in the current research were NGOs or social enterprises, and between them they catered for the needs of a wide range of end-beneficiary groups. Moreover, the students who had worked with the CPOs on service-learning projects majored in diverse disciplines. The authors, thus, believe the sample was sufficiently diverse to include a wide range of potential community impacts. 
Table 2. Profile of the interviewees, the CPOs represented by them, and the associated collaborations

\begin{tabular}{|c|c|c|c|c|c|}
\hline \multirow[t]{2}{*}{ No. } & \multirow[t]{2}{*}{ СРО Туре } & \multirow{2}{*}{$\begin{array}{l}\text { CPO's Service } \\
\text { Targets }\end{array}$} & \multicolumn{2}{|l|}{ Interviewees' Profile } & \multirow{2}{*}{$\begin{array}{c}\text { Collaborating } \\
\text { University }\end{array}$} \\
\hline & & & Position & Gender & \\
\hline R01 & $\mathrm{NGO}$ & Elderly people & $\begin{array}{c}\text { Senior Supervisor of Social } \\
\text { Services Division }\end{array}$ & Female & $\mathrm{LU}$ \\
\hline R02 & $\mathrm{NGO}$ & $\begin{array}{l}\text { Low income } \\
\text { families }\end{array}$ & Project Manager & Male & $\mathrm{LU}$ \\
\hline R03 & $\begin{array}{c}\text { Social } \\
\text { Enterprise }\end{array}$ & Women & General Secretary & Female & $\mathrm{LU}$ \\
\hline R04 & $\mathrm{NGO}$ & $\begin{array}{l}\text { The public } \\
\text { including } \\
\text { international } \\
\text { visitors }\end{array}$ & $\begin{array}{c}\text { Assistant Discovery \& } \\
\text { Education Manager }\end{array}$ & Male & $\mathrm{LU}$ \\
\hline R05 & $\begin{array}{c}\text { Social } \\
\text { Enterprise }\end{array}$ & Elderly people & $\begin{array}{c}\text { Senior Supervisor of } \\
\text { Community Support Centre }\end{array}$ & Male & LU \\
\hline R06 & $\mathrm{NGO}$ & $\begin{array}{l}\text { Elderly people } \\
\text { (dementia) }\end{array}$ & $\begin{array}{c}\text { Senior Supervisor } \\
\text { (Counselling and Caring } \\
\text { Service Team) }\end{array}$ & Female & LU \\
\hline R07 & $\mathrm{NGO}$ & $\begin{array}{l}\text { Primary School } \\
\text { Children }\end{array}$ & $\begin{array}{c}\text { Registered Social Worker/ } \\
\text { Officer-in-charge }\end{array}$ & $\begin{array}{c}\text { Female/ } \\
\text { Male }\end{array}$ & EdUHK \\
\hline R08 & $\begin{array}{c}\text { Social } \\
\text { Enterprise }\end{array}$ & $\begin{array}{c}\text { Masters of } \\
\text { traditional } \\
\text { craftsmanship in } \\
\text { Hong Kong }\end{array}$ & $\begin{array}{c}\text { Senior Corporate Affairs \& } \\
\text { Marketing Manager }\end{array}$ & Female & HKBU \\
\hline R09 & $\mathrm{NGO}$ & $\begin{array}{l}\text { Primary School } \\
\text { Children }\end{array}$ & Centre-in-charge & Female & EdUHK \\
\hline R10 & $\begin{array}{c}\text { NGO / } \\
\text { Social } \\
\text { Enterprise }\end{array}$ & $\begin{array}{l}\text { Patients / Low } \\
\text { income groups }\end{array}$ & Senior Program Manager & Female & HKBU \\
\hline R11 & $\begin{array}{c}\text { Aided } \\
\text { school } \\
\text { (private) }\end{array}$ & $\begin{array}{c}\text { Secondary } \\
\text { School Children }\end{array}$ & Vice-principal & Male & HKPU \\
\hline R12 & $\begin{array}{c}\text { NGO } \\
\text { (Inter- } \\
\text { national) }\end{array}$ & $\begin{array}{l}\text { Rural families in } \\
\text { poverty }\end{array}$ & Program Manager & Male & HKPU \\
\hline R13 & $\begin{array}{c}\text { NGO } \\
\text { (Inter- } \\
\text { national) }\end{array}$ & $\begin{array}{l}\text { Rural families in } \\
\text { poverty }\end{array}$ & the Founder & Female & HKPU \\
\hline
\end{tabular}


Table 3. Distribution of types of project across the types of CPO

\begin{tabular}{|l|l|l|l|l|}
\hline & \multicolumn{4}{|c|}{ Service-Learning Type* } \\
\hline CPO Type & Direct Service & Indirect Service & Research & Advocacy \\
\hline NGO & $\begin{array}{l}\text { R1, R2, R4, R5, } \\
\text { R7, R9, R10, R11 }\end{array}$ & R2, R4, R11 & R2 & R2, R5 \\
\hline Social Enterprise/ Private & R3, R8 & R3, R6, R8, R10 & R6 & R8, R10 \\
\hline $\begin{array}{l}\text { International Partners (both are } \\
\text { NGOs) }\end{array}$ & R12, R13 & & & R13 \\
\hline
\end{tabular}

Note: Please refer to the definitions provided by The University of Minnesota Community

Service-Learning Center (2020).

\section{Interview Protocol and Procedures}

After CPOs accepted the invitation, representatives from them, who carried knowledge about previous service-learning projects were selected for interview. The nominees were contacted by the research team for interview arrangements, and at that time were briefed about the focus of the interview and assured of data confidentiality. With one exception, nominees agreed to a face-toface interview. In the exception case, a combination of telephone and online video conferencing was used. Before each interview, the research team obtained consent from the interviewees regarding their voluntary participation and their support of an audio or video recording of the interview.

Each interview lasted between 60 and 130 minutes and followed an interview protocol that was divided into four sections. First, interviewees were asked to relate critical incidents to their experiences and observations of projects they perceived to have been relatively successful or unsuccessful in terms of impact on their own CPOs and/or for their community. Second, interviewees were asked to share their perceptions and suggestions about aspects of project management that could enhance community impact. For example, "What do you think could be done before or during a service-learning project in order to facilitate students' learning in ways that could increase their potential to provide positive community impacts?"

Third, interviewees were asked to explain their perceptions of the benefits and costs for their CPOs and for end-beneficiaries, which had arisen from collaboration in service-learning. For example, "From your experience, what benefits has service-learning brought to your organization/ clients/ service targets? Please give me an example." Fourth, interviewees were asked to comment on and provide explanations about any aspects of the service-learning projects and/or the associated collaborations that had been particular sources of satisfaction or dissatisfaction for them and/or other stakeholders. 


\section{Data Analysis}

The recordings of the interviews were transcribed by the second and third authors. Each transcript was then reviewed and coded by the research team. Coding was based on an inductive approach (Charmaz, 2006) for creating subcategories within the parameters of Figure 1 . The emerging category system was compared against the full dataset with iterations, using techniques such as storyline (Chun Tie, Birks, \& Francis, 2019), until saturation.

\section{Findings}

Positive Impacts for CPOs

As categorized in Table 4a, interviewees indicated that the main benefits that service-learning had brought to the respective CPOs comprised: (a) achieving intended project outcomes and thereby contributing to their mission; (b) establishing or enhancing relationships with their stakeholders; (c) obtaining resources to augment service capacity; and (d) gaining new knowledge/ insights/ techniques. Next, the authors shall provide illustrations of these various benefits.

Table 4a. Categories and Mentions of Positive Impacts

Overarching Categories

Achieving project goals to further the CPO's mission

Establishing/ enhancing the CPO's stakeholder relationships

Augmenting the resources of the CPO

Knowledge, insights/ideas, techniques for the CPO

Positive impacts for end-beneficiaries/ community
Frequency of mentions

87

Total 


\section{Achieving project goals to further the CPO's mission.}

Many interviewees reported that service-learning projects had given rise to valuable outputs, which had enhanced the CPO's existing services, or had helped the CPO to create new services.

Table 4b. Categories and Mentions of Positive Impacts on Achieving Project Goals to Further the CPO's Mission (Corresponding to CPO's Goals and Values Realized in Figure 1)

\begin{tabular}{lc}
\hline Positive Impact Categories & Frequency of mentions \\
\hline Tangible project output/ contribution & 27 \\
Enhanced the CPO's service & 20 \\
Helped to achieve partner goals & 15 \\
Promoted the CPO's service & 14 \\
Enhanced sense of satisfaction & 7 \\
More opportunities & 4 \\
\hline Total & $\mathbf{8 7}$ \\
\hline
\end{tabular}

For example, students in one service-learning project helped to edit and publish a book about the food recycling service of the $\mathrm{CPO}$, which featured interviews with end-beneficiaries. The respective interviewee indicated that the project achieved the goals of engaging end-beneficiaries in interviews and of promoting the CPO and its food recycling service.

I felt impressed with...this book. It was made by the practicum students...We also invited the course's professor to write the preface... The students interviewed people in the neighborhood and reported their stories... We needed materials like this book, so that we could introduce our services to our residents and show how these have been valued by others... (R2)

Some interviewees referred to other kinds of contribution by students, which they regarded as having furthered the mission of the $\mathrm{CPO}$ by increasing the number of clients that the $\mathrm{CPO}$ was able to serve. For example, in one project, students helped to operate booths and conduct games as means to advocate environmental protection, stating, "We really earned a very tangible reward from the program. They [the students] could reach out to several thousands ..." (R4)

\section{Establishing/enhancing the CPO's stakeholder relationships.}

Nine relevant quotes were collected in this category without further sub-categories being identified. One interviewee explained how students helped to advance the respective CPO's mission of promoting traditional local craftsmanship by persuading some local artisans to be video recorded while sharing their skills and experience. The students helped to shoot and edit the video for sharing with the public. The interviewee said: 
The artisans were willing to cooperate with the students for free because they saw this as a one-off commitment to help the students with their assignment. Previously, when we tried to enlist the artisans ourselves, some of them had been reluctant, and considered that they should be paid for their participation. (R8)

In the above case, the students served as a bridge, enabling the CPO to establish relationships with artisans. An interviewee from another CPO explained that relationships formed with students through service-learning collaboration had helped his organization to connect with customers:

A former student visited me and asked if I remembered her. She told me that she once undertook service-learning in our enterprise. She then worked for the Human Resources department in a company and would like to order some Christmas party gifts from our enterprise. Some other previous students also told me that they had sent my name card to their bosses... So, students would help open up channels for promoting our social enterprise in the longer term. (R5)

\section{Augmenting the resources of the CPO.}

Another type of positive impact for CPOs entailed gaining temporary resources to augment their normal capacity.

Table 4c. Categories and Mentions of Positive Impacts on Augmenting the Resources of the CPO (Corresponding to CPO's Capacity in Figure 1)

\begin{tabular}{lc}
\hline Positive Impact Sub-categories (where applicable) & Frequency of mentions \\
\hline More human resources & 15 \\
Shared/ reduced workload & 9 \\
More support & 4 \\
More positive work environment & 4 \\
More resources generally & 3 \\
Larger capacity to serve clients & 2 \\
Manpower development & 2 \\
Reduced expenses/ costs & 2 \\
\hline Total & $\mathbf{4 1}$ \\
\hline
\end{tabular}

The most frequently mentioned factor in this regard referred to human resources, reflecting that interviewees considered that the additional manpower provided by students in undertaking service-learning helped to reduce the workload of regular employees, increase the CPO's capacity to serve clients, and reduce its expenses. For example:

(C) The Author 2021. Published by the Coalition of Urban and Metropolitan Universities. www.cumuonline.org Metropolitan Universities | DOI 10.18060/25482| September 9, 2021 
Being able to allocate tasks to the university students reduced the workload of the regular tutors... so that each tutor could focus more attention on fewer children when handling their homework issues. (R7)

By arranging the service-learning projects, we increase the number of clients, whom we can serve, and we can also provide new activities for them. Besides, we improve the quality of the existing activities. (R13)

[The university] will provide suitable training for the students. This minimizes the time and administrative cost incurred for our full-time staff. Furthermore, the project is easier for me to handle. (R4)

I can say that because of the help of students and using the part-time standard rate as a yardstick for what we would otherwise have paid, we have saved HK\$100,000 dollars per annum. (R5)

Interviewees also indicated that besides furnishing the CPOs with resourceful partners (students), with whom they could co-create ideas and practices when implementing service-learning projects. Such projects served as a channel for identifying, attracting, and recruiting suitable students as employees after their graduation.

We can brainstorm together. Social enterprises lack human resources...The students are not treated as cheap labor, and we would like to co-create with them. (R8)

We plant the seeds in universities and ...we can have a stable supply of human resources with those students, who have completed service-learning. (R2)

In the context of international service-learning, interviewees explained that financial resources played a crucial role in enabling the respective $\mathrm{CPO}$ to achieve better service quality and expand its service scope.

The partner university obtained additional funding... and for the trip this year, the number of participants increased to 30 , among which were 24 students and three teachers from the university, and another three teachers from [another] university. (R10)

We need the resources and we need funds. So, if we don't have the funds and the resources, we can't operate. So, with that partnership [with the university], through [service-learning] projects, our organization has been able to reach out to needy people, and therefore, fulfilling the mission. (R12) 


\section{Knowledge, ideas/insights, techniques for the CPO.}

Knowledge: Some interviewees explained how students contributed knowledge that was helpful to the respective CPOs.

Table 4d. Categories and Mentions of Positive Impacts on Knowledge, Insights/Ideas Techniques for the CPO (Corresponding to Knowledge/Insights Gained by the CPO in Figure 1)

\begin{tabular}{lc}
\hline Positive Impact Sub-categories (where applicable) & Frequency of mentions \\
\hline New ideas, insights & 21 \\
New knowledge & 14 \\
New experience & 6 \\
Enhanced skills & 2 \\
\hline Total & $\mathbf{4 3}$ \\
\hline
\end{tabular}

For example:

As an NGO, our knowledge is limited, and the students could fill the gaps. For example, we needed to calculate the weight of the clothes that we collect, and the carbon dioxide emissions associated with our activities, but we didn't know how to do the calculations. The students informed us about the sources of the formulae from websites. (R11)

Ideas/insights. Many interviewees reported that students provided new ideas or insights that had not previously been considered. These ideas could sometimes inspire service innovations, as when students suggested applying skills that were being used for the embroidery of traditional Chinese shoes to the decoration of a modern luggage tag:

The students emphasized new ideas for the product... and the new product for embroidered shoes...The students linked up the shoe embroidery skills and applied it to decorate the luggage tag...For example, they embroidered my name on the tag... It was good for the students to approach the artisan about the "embroidered shoes"... and they had innovative ideas to transform the traditional product. (R8)

Interviewees observed that students' imagination was not confined by established structures and practices, and many of them treasured the creativity of students, whom they saw as outsiders with greater freedom to think "out of the box." For example:

I think [the students] have been most helpful with their creative ideas. Typically, when we [in this CPO] think of something new, we veto our own ideas. We will worry about where to find the money, where to find the place, what are the techniques? The students 
don't seem to have any of this burden, and I treasure this a lot. I just want them to talk about their ideas, even very weird ones. (R5)

Through discussions between students and experienced staff members, students' ideas could be tested and modified, and eventually some of them would become valuable assets for CPOs and their staff members. Most interviewees mentioned similar episodes of synergy, such as the following:

Most colleagues would be pre-occupied by regular duties and confined to existing ideas and practices. Through collaborating with ... students, we acquired new stimuli and ideas... [For example], the idea of "Aquaponics" impressed me a lot and this was very creative. I had learnt about that idea before but I had never thought that it could be executed in my place. (R6)

We may try out an idea if resources are available [in our CPO] or in the market... One example was about upcycling. Some manufacturers donate leather samples... We explained to the students that this large pile of leather samples should not be dumped in the landfills... They were outstanding and thought of knitting the leather into a hand strap. You can find that many young people have a leather hand strap, and also a wallet and purse, and many other things. (R10)

Techniques. Several interviewees mentioned gaining techniques based on students' IT abilities, for example:

[The students] are good at using Excel and PowerPoint. Through Forum and Instagram, they help a lot in passing on messages. Compared with our staff, the university students have absolute advantages in this aspect...We also learn from the students, for example, the techniques of using the internet and also functions within WhatsApp... (R10)

\section{Positive Impacts for End-beneficiaries/ Community}

Interviewees identified various kinds of beneficial impacts for end-beneficiaries, comprising some benefits that may have arisen directly from service-learning interventions, and others that may have come about indirectly via the CPOs, as a result of positive impacts of service-learning on the latter. 
Table 4e. Categories and Mentions of Positive Impacts on Positive Impacts for Endbeneficiaries/ Community (Corresponding to Needs Fulfilment/ Better Quality of Life for Endbeneficiaries in Figure 1)

\begin{tabular}{lr}
\hline Positive Impact Sub-categories (where applicable) & Frequency of mentions \\
\hline Positive impacts on end-beneficiaries generally & 47 \\
More participation by end-beneficiaries & 7 \\
Positive impacts for the community & 7 \\
Increased income & 4 \\
Better quality of life & 4 \\
Meaningful service & 3 \\
Sustainable contributions received by the community & 2 \\
& Sub-total \\
\hline
\end{tabular}

Some interviewees described what they perceived as substantial, positive impacts for endbeneficiaries that they attributed to service-learning projects. For example, one interviewee referred to the impacts for local residents, which arose from an international service-learning project that involved installing solar-powered lighting systems in remote villages in Cambodia:

[Before the installations] when it was dark, the children could not do their homework. But with solar-powered lighting, they can now do their homework between 6 and 8 p.m. That's something we regard as a major benefit for the education of children. Also, because of the lighting, their parents can oversee the surrounding household environment. This is very important for two reasons. First, security can be ensured as nobody can come and steal their property such as animals...Second, the parents can continue doing their work during the evening. [Before] when it was dark, they stopped and went to bed. (R12)

This interviewee also characterized students as intermediaries in the knowledge transfer process from universities, via the CPO, to the community.

We worked together with the university and their students to transfer knowledge and skills into community development ... It's the transfer of skills and knowledge that directly benefits the end users. (R12)

In this example, the tangible outputs of service-learning were solar power and the associated lighting provided for the local community, but there were also three additional benefits arising from these. The framework derived from Max-Neef (1991) given in Figure 1 can be used to categorize these impacts, as follows. First, enabling children to continue their studies met needs related to understanding-doing; second, improving household security met needs related to protection-having; third, enabling residents to extend working hours into the evening met needs 
related to subsistence-doing. Meeting these needs was perceived as having enhanced the villagers' quality of life.

Hong Kong based interviewees also provided examples of positive impacts for local endbeneficiaries. One such example involved a regular arrangement, under which cohorts of university students had run a STEM education program for junior students from a secondary school:

For the first session [of the STEM program], our S1 [secondary] students go to the university campus [receipt of education (understanding-having)] ... The university students serve as teachers, but the class is more like an interest class [fun (leisure-being)] ... [They] lead the S1 students to brainstorm how the technologies of STEM can be used to create solutions for problems [engaging in investigating (understanding-doing)] faced by elderly people. In response to the S1 students' ideas, they teach them [skill acquisition (creation-having)] how to produce prototypes [inventiveness (creation-being)]; [designing (creation-doing)] ... and how to present the products to the elderly people [actively participating in an educational setting (understanding-interacting)] ... Our S1 students, without any prior knowledge, can implement their ideas with the support of the university students [participating in a setting for production (creation-interacting)] ... Many, with no prior understanding of science, begin developing an interest in science [curiosity (understanding-being)]. When they are promoted to senior forms, they are more likely to choose science subjects ... They have extended their horizons... As they become mature, they experiment in S2 and S3 and learn more about science in S4 and S5. Last October, a group of our secondary students went overseas, participating in a well-known worldwide science competition, winning the bronze prize. (R11)

In the above account, as perceived by R11, the services provided by the university students undertaking service-learning project have not only given rise to immediate satisfaction and knowledge for the S1 students, but have also generated interest that has paved the way for the secondary students' subsequent participation in further STEM educational and project-based activities. As with the previous example, the Max-Neef (1991) needs fulfilment framework can be used to categorize the perceived impacts. In terms of immediate impacts of the STEM education session for the S1 students, the interviewee perceived that the latter had benefitted in terms of fulfilling the needs of curiosity and education. The interviewee also perceived that with the help of the university students, the S1 students had undertaken projects, through which they created simple prototypes, thereby benefitting in terms of skill acquisition and translating it into an inventive and innovative design for inspiring the community members. In addition, the session appeared to the interviewee to be like an interest class, potentially involving a form of leisure for the S1 students. 
Furthermore, the interviewee attributed the decision of some secondary students to pursue their interest in science through self-study and to undertake science subjects in subsequent years to the impact of the STEM education session provided by the university students, and even hinted that the evolution during years S2-S5 of the secondary students' sense of belonging within the science community could be attributed to this intervention.

\section{Discussion}

The current research indicates that from the perspective of representatives of CPOs, servicelearning projects undertaken by students from universities in Hong Kong were perceived to have had favourable community impacts. Moreover, the findings have confirmed the proposed model, paving the way for translating the model into institutional and practitioner guidelines for higher education institutions, including the urban and metropolitan universities. One tangible output of value to both the service-learning research and practitioner communities is that arising from the research, a Community Impact Feedback Questionnaire (CIFQ) has been developed (Lau \& Snell, 2021). The CIFQ has been designed to capture the community impacts arising from service-learning from the CPO's perspective, and is intended for practical use as a tool for improving service-learning programs. The remainder of this section recaps the main findings regarding community impacts, seeks to explain why these impacts arise from service-learning, relates findings to other recent research, acknowledges limitations, and identifies directions for further research.

\section{Positive Impacts for CPOs}

Consistent with the conceptual model in Figure 1, the three main types of perceived benefit for CPOs were: achieving project goals to further their mission; augmenting their resources; and gaining knowledge/ insights/ ideas/ techniques.

The first type of perceived benefit implies the need for alignment between the goals of the respective service-learning project and the CPO's mission. Such alignment requires collaboration between the $\mathrm{CPO}$ and the university during both planning and execution stages, as recommended by prior scholars (e.g., Mattessich \& Monsey, 1992; Wade, 1997).

The second type of perceived benefit reflects that NGOs and social enterprises in Hong Kong tend to face manpower shortages, and that students undertaking service-learning projects have been able to help fill this gap, thereby increasing the capacity of CPOs to serve clients without increasing workloads among regular employees. Some interviewees pointed out that in such cases the students were regarded as knowledge workers and not merely as "cheap labor" and that it was essential for the students to be fully inducted into the CPO's mission.

(C) The Author 2021. Published by the Coalition of Urban and Metropolitan Universities. www.cumuonline.org

Metropolitan Universities | DOI 10.18060/25482| September 9, 2021 
The third type of perceived benefit involved knowledge-related student contributions. Some of these contributions were described by interviewees as involving practical applications of functional expertise not possessed by the CPOs, typically within domains such as IT, social marketing, and engineering. Contributions of this kind could be characterized as involving a form of knowledge transfer from the university via the students to the CPOs.

Other descriptions by interviewees of students' knowledge-related contributions involved the latter introducing new ideas and fresh perspectives to the CPOs that interviewees considered valuable. As compared with regular employees, interviewees characterized students undertaking service-learning projects as semi-outsiders with fewer inhibitions against challenging existing practices or systems, and often expressing the perspective of a different generation vis-à-vis their host managers. While interviewees acknowledged that students' ideas and suggestions required careful evaluation, and were sometimes impracticable, they indicated that these could point the way toward practical service improvements and innovations. While this finding confirms previous research (Barrientos, 2010; Driscoll et al., 1996), it is important when assessing community impacts to ascertain whether tangible benefits are perceived to have come to fruition in practice.

The authors consider that students can constitute an organic synthesis of extra manpower and a source of new knowledge, skills and techniques for their host CPOs, as a result of the unique features of well-designed service-learning. An important design feature involves connecting service and academic content (Astin et al., 2000; Billig, 2007; Eyler \& Giles, 1999; Snell, Chan, Ma, \& Chan, 2015b). Without this connection, it may be difficult for students to transcend the role of volunteers and harness their knowledge and skills as assets for the community partners. In addition to academic content, students also drew on in their 21 st century talents and skills, such as computer literacy, marketing via social media (e.g., Forum and Instagram), and creativity (e.g., applying the shoe embroidery skills to the luggage tag), as required by their CPOs. A welldesigned service-learning project that is in triple alignment with academic content, graduate attributes, and community needs thus creates a uniquely powerful ecosystem that fosters win-win collaboration between students and CPOs, instead of merely supplying extra hands to relieve the CPO's work burden.

Findings for this paper are compatible with those of two other recent studies. Kindred (2020) identified both short-term and long-term benefits of service-learning for community partners in terms of organizational learning and extra capacity. Jetter, Pelco, and Elliot (2017) identified positive impacts from service-learning for a sample of $22 \mathrm{CPOs}$. They found that besides expanding organizational capacity, there were economic benefits arising from enhanced service value and fundraising activities, along with social benefits associated with building connections with the student body and the university, and reflected in the enhanced well-being of community members.

(C) The Author 2021. Published by the Coalition of Urban and Metropolitan Universities. www.cumuonline.org Metropolitan Universities | DOI 10.18060/25482| September 9, 2021 


\section{Positive Impacts for End-Beneficiaries}

As described by interviewees, some of the positive impacts for end-beneficiaries appeared to have arisen directly and immediately from service-learning projects, as with the bringing of solar-powered lighting to remote villages in Cambodia. Other positive impacts for endbeneficiaries appeared to have emerged over several years, as with the perceived ripple effects of the STEM education program for S1 secondary students at the partner secondary school. The authors may infer that in the latter case, some of the perceived benefits for the secondary school students as end-beneficiaries may have arisen indirectly, as a result of positive impacts of a series of service-learning interventions on the service quality and/or service capacity of the CPO (the secondary school).

The authors found that positive impacts for end-beneficiaries could be categorized with the MaxNeef (1991) typology of needs-fulfilment presented in Table 1, and that interviewees perceived needs-fulfilment for end-beneficiaries as being related to the enhancement of their quality of life.

\section{Limitations and Directions for Further Research into Community Impacts}

The current research provided qualitative support for the models of the community impacts of service-learning that are given in Table 1 and Figure 1, respectively, paving the way for the development of measurement instruments such as the CIFQ, mentioned above.

While the current research has provided pointers toward the likely impacts of service-learning projects on CPOs and end-beneficiaries, a major limitation is that it has drawn exclusively on the perspectives of CPO representatives. More complete understanding of the perceived impacts of service-learning projects on end-beneficiaries and other community residents is likely to require additional data collection. This could involve end-beneficiaries reporting their perceptions of the contributions of service-learning interventions to the fulfilment of their own needs and quality of life. Such studies could be guided by the Max-Neef (1991) typology, and might involve initial diagnosis of the most salient areas of need-fulfilment for end-beneficiaries from among the 36 possible domains (see Table 1), by first interviewing CPO representatives and/or by observing the service-learning intervention(s).

For example, regarding the STEM education case described above, R11 had already been interviewed, and expressed perceptions that there were immediate impacts on the S1 secondary school students in terms of their understanding-being, understanding-having, understandingdoing, understanding-interacting, creation-being, creation-having, creation-doing, creationinteracting, and leisure-being. R11 also surmised that there may have been longer-term impacts on the secondary school students in terms of their identity-being vis-à-vis the science community. In a follow-up study of community impacts, current and former S1 students could be 
interviewed systematically about their corresponding perceptions of such impacts. Their perceptions may challenge, corroborate or augment the perceptions of R11, the CPO representative. Such studies may be carried out longitudinally, tracing impacts over several years, and may also involve action research, as findings are fed back to inform the design and implementation of subsequent service-learning interventions.

Studies of community impact from the students' perspective are notably absent. Their perceptions on how service-learning impacts the communities that they serve also warrant attention.

Finally, this paper has not, until this point, mentioned adverse impacts arising from servicelearning projects. Interviewees commented that on occasion, desired outcomes for the respective CPO had not been met and that, associated with this, there had been some perceived wastage of time and resources. The authors consider that such cases could be prevented by thorough and accurate need diagnosis, appropriate student preparation and training, careful management of partner expectations, and due consideration of the workload implications for students. These aspects, along with the incidence of adverse community impacts, are also topics for future research.

\section{Author Note}

This paper results from a cross-institutional project named "Cross-institutional Capacity Building for Service-Learning in Hong Kong Higher Education Institutions (PolyU4/T\&L/16-19)" which aims to enhance and support the development of service-learning as an effective pedagogical strategy under the collaboration of Lingnan University, The Hong Kong Polytechnic University, Hong Kong Baptist University, and The Education University of Hong Kong. The project was launched in 2017 and has been funded by the University Grants Committee (UGC) of the Hong Kong Special Administrative Region (HKSAR) government. The authors wish to thank the UGC for funding the project, and the above institutions for their participation in the process. 


\section{References}

Astin, A. W., Vogelgesang, L. J., Ikeda, E. K., \& Yee, J. A. (2000). How service-learning affects students. Los Angeles, CA: Higher Education Research Institute, UCLA. Retrieved from https://digitalcommons.unomaha.edu/slcehighered/144.

Barrientos, P. (2010). Community service-learning and its impact on community agencies: An assessment study. CA: Institute for Civic and Community Engagement.

Billig, S.H. (2007). Unpacking what works in Service-Learning: Promising research-based practices to improve student outcomes. In J. Kielsmeier, M. Neal, and N. Schultz (Eds.), Growing to greatness 2007: The state of service-learning. Saint Paul, MN: National Youth Leadership Council.

Bringle, R. G., \& Hatcher, J. A. (1996). Implementing service learning in higher education. Journal of Higher Education, 67(2), 221-239

Bringle, R. G., Philips, M. A., \& Hudson, M. (2004). The measure of service-learning: research scales to access student experiences. Washington, DC: American Psychological Association.

Charmaz, K. (2006). Constructing grounded theory: a practical guide through qualitative analysis. Thousand Oaks, CA: SAGE.

Chun Tie, Y., Birks, M., \& Francis, K. (2019). Grounded theory research: A design framework for novice researchers. SAGE Open Medicine, 7, 205031211882292. https://doi.org/10.1177/2050312118822927

Clarke, M. M. (2003). Finding the community in service-learning research: The 3-"I" model. In S. H. Billing \& J. Eyler (Eds.), Deconstructing service-learning (pp. 3-21). Nashville: Information Age Publishing.

Cruz, N., \& Giles, D. E., Jr. (2000). Where's the community in service-learning research? Michigan Journal of Community Service Learning, 7(1), 28-34.

Driscoll, A., Holland, B., Gelmon, S., \& Kerrigan, S. (1996). An assessment model for servicelearning: comprehensive case studies of impact on faculty, students, community, and institution. Michigan Journal of Community Service Learning, 3, 66-71.

Eyler, J. S., \& Giles, D. E. (1999). Where's the learning in service learning? San Francisco, CA: Jossey-Bass.

(C) The Author 2021. Published by the Coalition of Urban and Metropolitan Universities. www.cumuonline.org Metropolitan Universities | DOI 10.18060/25482| September 9, 2021 
Eyler, J. S., Giles, D. E., Stenson, C. M., and Gray, C. J., (2001). At a glance: What we know about the effects of service-learning on college students, faculty, institutions and communities, 1993-2000. (3rd ed.) Nashville, Tenn.: Vanderbilt University Press.

Farahmandpour, H., \& Shodjaee-Zrudlo, I. (2015) Redefining Service-Learning for the Purpose of Social Change within Education. In Bola Delano-Oriaran, Marguerite W. Penick-Parks, \& Suzanne Fondrie (Eds.) The SAGE sourcebook of service-learning and civic engagement, Chapter 7. CA: SAGE.

Felten, P., \& Clayton, P. H. (2011). Service-Learning. New Directions for Teaching and Learning, 128, 75-84. https://doi.org/10.1002/t1.470

Gelmon. S. B. (2003). Assessment as a means of building service-learning partnerships. In B. Jacoby \& Associates (Eds.). Building partnerships for service-learning (pp. 42-64). San Francisco: Wiley.

Giles, D. E., \& Eyler, J. (1998). The theoretical roots of service-learning in John Dewey: Toward a theory of service-learning. Michigan Journal of Community Service Learning, 1(1), 7785. Retrieved from http://hdl.handle.net/2027/spo.3239521.0001.109

Holland, B. A. \& Gelmon, S. B. (1998). The state of the "England Campus": What have we learned about building and sustaining university-community partnerships. AAHE Bulletin, 51, 3-6.

Jacoby, B. (1996). Service-Learning in higher education: concepts and practices. San Francisco: Jossey-Bass.

Jettner, J. F., Pelco, L. E., \& Elliott, K. L. (2017). Service-Learning Community Partner Impact Assessment Report. Virginia Commonwealth University, Richmond, VA.

Kellogg, W. (1999). Toward more transformative service-learning: Experiences from an urban environmental problem-solving class. Michigan Journal of Community Service Learning, 6(1), 63-73.

Kindred, J. (2020). Nonprofit partners' perceptions of organizational and community impact based on a long-term academic service-learning partnership. Journal of Community Engagement and Scholarship, 13(1), Article 8.

Lau, K. H., \& Snell, R. S. (2020). Assessing community impact after service-learning: A conceptual framework. Presented at the 6th International Conference on Higher Education Advances (HEAd'20), Valencia, Spain, 2020. 
Lau, K. H., \& Snell, R. S. (2021). Community impact feedback questionnaire (CIFQ): The user manual. Hong Kong: Office of Service-Learning, Lingnan University. doi: https://doi.org/10.14793/9789887522218

Ma, C. (2018). Service-learning development in higher education in Hong Kong. In T. W. Lim \& W. X. Li (Eds), Studying Hong Kong: 20 years of political, economic and social developments (pp. 43-61). New Jersey: World Scientific. https://doi.org/10.1142/9789813223554_0004

Mattessich, P. W., \& Monsey, B. R. (1992). Collaboration: What makes it work. A review of research literature on factor influencing successful collaboration. St. Paul, MN: Amherst H. Wilder Foundation.

Max-Neef, M. A. (1991). Human scale development: Conception, application and further reflections. New York, NY: Apex Press.

Ngai, S. S. (2006). Service-learning, personal development, and social commitment: A case study of university students in Hong Kong. Adolescence, 41, 165-176. Retrieved from https://www.ncbi.nlm.nih.gov/pubmed/16689448

Ngai, S. S. (2009). The effects of program characteristics and psychological engagement on service-learning outcomes: A study of university students in Hong Kong. Adolescence, 44, 375-389. Retrieved from https://www.ncbi.nlm.nih.gov/pubmed/19764273

Shek, D. \& Chan, S. (2013) Service-learning from the views of university teachers: a qualitative study based on focus groups. International Journal of Adolescent Medicine and Health, 25(4), 385-393. https://doi.org/10.1515/ijamh-2013-0036

Shumer, R., Stanton, T. K. and Giles D. E., Jr. (2017), History and precursors of service-learning theory, development and research. In Robert Shumer (Ed.) Where's the wisdom in servicelearning? NC: Information Age Publishing.

Snell, R. S., Chan, M. Y. L., Ma, C. H. K., \& Chan, C. K. M. (2015a). Developing civicmindedness in undergraduate business students through service-learning projects for civic engagement and service leadership practices for civic improvement. Asian Journal of Business Ethics, 4(1), 73-99. https://doi.org/10.1007/s13520-015-0044-0

Snell, R. S., Chan, M. Y. L., Ma, C. H. K., \& Chan, C. K. M. (2015b). A road map for empowering undergraduates to practice service leadership through service-learning in teams. Journal of Management Education, 39(3), 372-399. https://doi.org/10.1177/1052562914545631 
Snell, R. S. \& Lau, K. H. (2020). The Development of a Service-learning Outcomes Measurement Scale (S-LOMS). Metropolitan Universities, 31(1), 44-77. https://doi.org/10.18060/23258

Toncar, M. F., Reid, J. S., Burns, D. J., Anderson, C. E., \& Nguyen, H. P. (2006). Uniform assessment of the benefits of service learning: the development, evaluation, and implementation of the SELEB scale. The Journal of Marketing Theory and Practice, 14(3), 223-238. https://doi.org/10.2753/mtp1069-6679140304

University of Minnesota Center for Community-Engaged Learning (2011). Direct, indirect, research, and advocacy engagement. Retrieved from $\underline{\mathrm{http}: / / \mathrm{ccel}-}$ app.umn.edu/cesp/programdetails/engagement types.html

Wade, R. C. (1997). Community service-learning: A guide to including service in the public school curriculum. NY: State University of New York Press. 